\title{
NADMIERNE KORZYSTANIE Z URZĄDZEŃ MOBILNYCH WŚRÓD DZIECI
}

\begin{abstract}
Nowak Joanna, Nadmierne korzystanie z urządzeń mobilnych wśród dzieci [Excessive Use of Mobile Devices Among Children]. Studia Edukacyjne nr 51, 2018, Poznań 2018, pp. 469-478. Adam Mickiewicz University Press. ISSN 1233-6688. DOI: 10.14746/se.2018.51.28

The article deals with the excessive use of mobile devices by children and students. The article draws attention to the earlier children's contact with devices and public applications. The article presents the possible causes of this phenomenon and the resulting threats. The article has a theoretical and research character.
\end{abstract}

Key words: mobile technologies, Network, interpersonal relations

\section{Wstęp}

Współczesny świat znacznie różni się od realiów, jakie miały miejsce jeszcze kilkadziesiąt lat temu. Przyjęło się mówić, że to już nie te czasy, kiedy dziecko słuchając rad starszych - sądzono wtedy mądrzejszych osób - poznawało otaczający świat. Obecnie spacer z rodzicami i obserwowanie przyrody nie jest konieczne, aby malec po raz pierwszy zobaczył kolorowego motyla. Bardzo często zdarza się, że małe dziecko poznaje otaczającą go rzeczywistość za pomocą dobrze znanych mu narzędzi - telefonu komórkowego, laptopa lub telewizji. Dla wielu osób starszych trudne do zaakceptowania jest to, że ich wnuk, wnuczka ma problem z rozpoznaniem krowy bądź konia, zastanawia się jaka jest prawidłowa kolejność sadzenia roślin tak, by w późniejszym czasie wydały owoce. Dla każdego dziadka lub babci mieszkającego w mieście lub żyjącego na wsi jest to wiedza podstawowa. Teraz wielu uczniów szkół podstawowych ma problem z odpowiedzią na ogólne pytania dotyczące przyrody, zwierząt i tym podobne. Sporym ułatwieniem dla dzie- 
ci okazują się informacje dostępne w małych urządzeniach, które zazwyczaj mają cały czas przy sobie - telefonie komórkowym, tablecie. Dzieci i młodzież są przekonane, że "Google wie wszystko". Rzeczywistość, w której obecnie funkcjonujemy stwarza ludziom wiele możliwości. Z udogodnień tych korzystają zarówno osoby starsze, jak i dzieci. Nikogo już nie dziwi widok małego dziecka, które nie potrafi jeszcze wypowiedzieć krótkiego zdania, za to świetnie posługuje się telefonem swoich rodziców.

\section{Dzieciństwo wśród urządzeń mobilnych - dostęp do nowych technologii od najmłodszych lat}

Bardzo często na polskich ulicach można dostrzec młode mamy, które korzystając z pięknej pogody, wychodzą na spacer ze swoimi pociechami. Podczas tego typu wędrówek powinny one podziwiać otaczającą przyrodę, nasłuchiwać odgłosów ptaków, starać się zapamiętać każdy szczegół. Jest to niewątpliwie obraz idealny. Zazwyczaj cała sytuacja wygląda zupełnie inaczej. Młoda mama wychodząc na spacer z dzieckiem, nie może zapomnieć dwóch rzeczy - telefonu i powerbanku. Biorąc pod uwagę, że spacer bez dziecka nie miałby większego sensu, potrzebny będzie również wózek i mała pociecha - syn lub córka. Dla wielu kobiet spacer z dzieckiem stanowi jedną z nielicznych okazji, by w spokoju porozmawiać ze znajomymi, rodzicami i tym podobnie. Jest to zadanie trudne do zrealizowania, ponieważ dziecko wymaga stałej uwagi, zainteresowania. Wszystko jest dla niego ciekawe, kolorowe, chciałoby dotknąć, powąchać to, co jest tak blisko niego. Niestety, to niekorzystna sytuacja dla wszystkich pań, które zaplanowały w tym czasie rozmowy telefoniczne z najbliższymi. Aby zaproponować coś swoim dzieciom i zyskać czas dla siebie, zazwyczaj podają one dziecku tablet lub telefon komórkowy z dużym kolorowym wyświetlaczem. Na ekranie pojawiają się zabawne zwierzątka, rytmicznie się poruszając i uśmiechając do dziecka. W tym momencie większość pań uświadamia sobie, że wychodząc na spacer, potrzebuje więcej rzeczy niż przypuszczała - oprócz telefonu i powerbanku wymagany jest również sprzęt dla dziecka.

Wiele dorosłych osób zastanawia się, kiedy małe dziecko po raz pierwszy może korzystać z urządzeń mobilnych. Opublikowany i ogólnie dostępny raport z badania „Korzystanie z urządzeń mobilnych przez małe dzieci w Polsce" pokazuje, jak popularne są wśród najmłodszych takie urządzenia, jak smartfon lub tablet. Na stronie internetowej umieszczone są dokładne wyniki badań. Okazuje się, że prawie połowa rocznych i dwuletnich dzieci korzysta z tabletów lub smartfonów. Wielu rodziców, którzy udostępniają dzieciom urządzenia, robi to, żeby zająć się swoimi sprawami ${ }^{1}$.

\footnotetext{
${ }^{1}$ http:/ / mamatatatablet.pl/ [dostęp: 25.02.2019].
} 
W Stanach Zjednoczonych bardzo popularne są tablety dla niemowląt. Przeprowadzone wśród 900 rodziców badania pokazały, że połowa dzieci poniżej 12. miesiąca życia ogląda telewizję, ponad 30\% niemowląt obsługuje ekran dotykowy, 15\% dzieci poniżej 1. roku życia ma kontakt z aplikacjami mobilnymi, a 12\% maluchów gra w gry komputerowe. Badani rodzice potwierdzili, że zazwyczaj pozwalają swym dzieciom korzystać z urządzeń mobilnych, kiedy sami mają do wykonania zadanie związane z obowiązkami domowymi lub zawodowymi. Ponad połowa rodziców twierdzi, że dostęp do urządzeń mobilnych uspokaja ich dzieci, a prawie 30\% badanych osób dorosłych pozwala niespełna rocznym dzieciom korzystać z urządzeń mobilnych przed zaśnięciem².

\section{Zabawa jako potrzeba każdego dziecka}

Zabawa, według Czesława Kupisiewicza, to

jedna z głównych form aktywności człowieka - obok nauki i pracy - podejmowana dobrowolnie, niemająca charakteru utylitarnego, połączona z pozytywnymi doznaniami emocjonalnymi, a często również poznawczymi ${ }^{3}$.

Wincenty Okoń zdefiniował pojęcie zabawy jako:

działalność wykonywana dla przyjemności, którą sama sprawia; prócz pracy, której celem jest zmiana otaczającej rzeczywistości, i uczenia się, mającego na celu zmianę podmiotu 4 .

Obydwie definicje zmierzają do podkreślenia opinii, iż zabawa to forma aktywności dzieci w czasie wolnym i stanowi naturalny sposób zaspokojenia zainteresowań oraz potrzeb dziecka.

Wielu rodziców w natłoku obowiązków zapomina, jak ważną rolę w życiu każdego dziecka pełni zabawa. Jest ona przejawem biologicznych i psychicznych jego potrzeb, które wraz z rozwojem się zmieniają ${ }^{5}$. To właśnie zabawa stanowi główny rodzaj działalności dziecka. Umożliwia eksperymentowanie konkretem, a następnie rozumem. Stanowi niezbędny atrybut dzieciństwa, sposób istnienia człowieka w początkowych latach życia. Uważa się zabawę za przejaw beztroskiej, wymagającej mniejszej uwagi aktywności dzieci, a zarazem dopatruje się w niej ogromnych wartości osobotwórczych, a wręcz nawet pracotwórczych. Dzieci niezmiennie od wieków bawią się, dowodzi to wręcz wrodzonej istoty zabawy, czyli pierwszej potrzeby zaistnienia w świecie. Toru-

${ }^{2}$ M. Spitzer, Cyberchoroby. Jak cyfrowe życie rujnuje nasze zdrowie, Słupsk 2016, s. 235.

${ }^{3}$ C. Kupisiewicz, M. Kupisiewicz, Stownik pedagogiczny, Warszawa 2009, s. 198.

${ }^{4}$ W. Okoń, Stownik pedagogiczny, Warszawa 1984, s. 358.

${ }^{5}$ A. Klim-Klimaszewska, Pedagogika przedszkolna, Warszawa 2010, s. 39. 
je ona drogę od uczucia do zorganizowanego działania. Uznaje się ją za strategię edukacyjną, ponieważ jej wartość wspiera człowieka w jego rozwoju, zwracając przy tym uwagę na rolę wielu czynników i warunków oddziałujących na siebie. Dziecięcą zabawę można porównać z pracą, która jest podejmowana dobrowolnie, nie liczy się z końcowym efektem, zawsze łączy się z przyjemnością. Dziecko stawia sobie określone cele i dąży wytrwale do ich realizacjí.

Nadmierne korzystanie z urządzeń mobilnych od najmłodszych lat może niekorzystnie wpływać na rozwój dziecka i jego umiejętności. Realne manipulowanie przedmiotami, łączenie różnych kanałów zmysłów przyczynia się do prawidłowego rozwoju dziecka. Wszystkie osoby dorosłe, które mają kontakt z dziećmi, zajmują się ich wychowaniem, nauczaniem lub sprawują nad nimi opiekę, muszą wiedzieć, że dziecko, aby poznać otaczającą rzeczywistość musi dotknąć, powąchać, zobaczyć i posmakować tego co go interesuje. Nie wystarczy dostęp do nowoczesnych technologii, ono musi mieć kontakt $\mathrm{z}$ rzeczywistością i bliskimi mu osobami. $\mathrm{W}$ tym okresie liczy się praktyczna działalność dziecka i jego relacje z dorosłymi .

\section{Przyczyny nadmiernego korzystania z urządzeń elektronicznych oraz jego skutki}

W wielu sytuacjach należy zastanowić się, dlaczego dzieci tak często korzystają z urządzeń mobilnych. Być może przyczyna tkwi w relacjach z najbliższymi osobami - rodzicami, przyjaciółmi, znajomymi. Warto pamiętać, że każdy z nas chce być akceptowany, chce czuć się dobrze w gronie bliskich mu osób ${ }^{8}$. Podobny pogląd można odnaleźć w wielu innych publikacjach. Joachim Bauer w książce zatytułowanej Co $z$ tą szkota? potwierdza, jak ważna jest akceptacja i uznanie dziecka przez osoby dorosłe.

Poczucie własnej wartości może rozwinąć się w dziecku tylko wtedy, gdy ma ono przeświadczenie, że jest ważne dla bliskich mu osób; jedynie wtedy będzie przekonane, że jego życie ma sens i że dlatego warto dążyć do obranego celu9

We współczesnym, szybko zmieniającym się świecie relacje między dorosłymi a dziećmi ulegają zmianom. Nie zmienia się jednak podstawowy fakt, że każde dziecko potrzebuje bliskości osób dorosłych, które będą mieć dla

${ }^{6}$ D. Waloszek, Pedagogika przedszkolna. Metamorfoza statusu i przedmiotu badań, Kraków 2006, s. 253-256.

${ }^{7}$ M. Spitzer, Cyberchoroby, s. 235.

${ }^{8}$ G. Hüther, U. Hauser, Wszystkie dzieci sa zdolne. Jak marnujemy wrodzone talenty, Słupsk 2014, s. 30 .

${ }_{9}^{9}$ J. Bauer, Co z tą szkołą? Siedem perspektyw dla uczniów, nauczycieli i rodziców, Słupsk 2015, s. 21. 
niego wystarczającą ilość czasu. Jesper Jull w jednej ze swych książek zwrócił uwagę na bardzo ważny szczegół w życiu wielu rodzin. Osoby dorosłe - rodzice, opiekunowie - od najmłodszych lat dziecka myślą i planują jego przyszłość. Zastanawiają się, jaką uczelnię wybrać dla swojego zdolnego syna lub bardzo zdolnej córki. Wszystko to powoduje, że małe dziecko czuje się osamotnione. Jego rodzice zamiast spędzać z nim beztrosko czas, planują bardzo odległą przyszłość ${ }^{10}$. Wszystkie te przykłady bardzo dokładnie ilustrują, jak ważna jest obecność dorosłych w życiu małych dzieci. Należy pamiętać, że każdy malec niezależnie od wieku chce być kochany i akceptowany przez osoby z jego otoczenia. Niekiedy dzieci korzystające z urządzeń mobilnych rekompensują sobie pewne braki. W gronie wirtualnych znajomych cieszą się szacunkiem i uznaniem, dlatego rezygnują z utrzymywania relacji z najbliższymi. Wiele dorosłych osób powinno zastanowić się, czy jego dziecko nie poświęca zbyt dużo czasu na korzystanie z urządzeń mobilnych. Wszelkie urządzenia tego typu są dla dzieci bardzo atrakcyjne ze względu na dostępność, nieograniczony limit czasowy. Tablet, w wielu przypadkach, staje się najlepszym przyjacielem dziecka, który nigdy nie odmówi mu spędzenia wspólnie czasu. Oczywiście, nie można generalizować, jednak w wielu przypadkach dzieci, które nie mają zorganizowanego czasu wolnego i nie mogą liczyć na realną obecność rodziców decydują się na wirtualne spędzanie wolnego czasu. Wszystkie dorosłe osoby powinny pamiętać, że czas, jaki poświęcamy dziecku jest fundamentem relacji między osobami.

Codzienne, często nadmierne, korzystanie z nowoczesnych urządzeń mobilnych może wynikać z faktu, że komputer, smartfon lub telewizja stają się bardzo łatwym sposobem na nudę. Współczesne dzieci nie muszą mobilizować się do intensywnego myślenia nad tym, co będą robić w wolnym czasie, nie pobudzają swej wyobraźni, by stworzyć nową zabawę. Obecnie wystarczy wziąć do ręki urządzenie, kliknąć przycisk i każdy jest już czymś zajęty. Dla wielu rodziców jest to sytuacja trudna do zaakceptowania, bowiem przyzwyczajeni są do innych sposobów spędzania wolnego czasu. Nie należy jednak zapominać, że to osoby dorosłe dopuściły dzieci do urządzeń mobilnych, bardzo często instalując telewizor lub komputer $\mathrm{w}$ dziecięcych pokojach ${ }^{11}$. Osoby dorosłe powinny zapoznać się z publikacjami dotyczącymi wpływu mediów na rozwój dziecka. Te, które wiele godzin spędzają przed szklanym ekranem narażone są na osiąganie słabszych wyników w nauce, bowiem ich potencjał intelektualny, podobnie jak i talent, zanika. Zależność między czasem spędzonym przed telewizorem, komputerem bądź tabletem a zdolnościami dzieci jest ujemna ${ }^{12}$.

${ }^{10}$ J. Jull, Kryzys szkoty. Co możemy zrobić dla uczniów, nauczycieli i rodziców? Podkowa Leśna 2014, s. 27.

${ }^{11}$ G. Hüther, U. Hauser, Wszystkie dzieci sa zdolne, s. 40-41.

12 J. Bauer, Co z tą szkota? s. 104-105. 
O negatywnym wpływie korzystania z urządzeń mobilnych przez dzieci i młodzież pisał również Michel Desmurget. W swej książce zwrócił uwagę na bardzo ważną kwestię, związaną z zależnością między doświadczeniami z dzieciństwa a dorosłą przyszłością. Dziecko, które spędza przed telewizorem kilka lub kilkanaście godzin dziennie może zmagać się z nadwagą, a w przyszłości z otyłością. Nastolatka oglądająca seriale promujące zachowania ryzykowne ma większe prawdopodobieństwo zajścia w nieplanowaną ciążę lub zarażenia się chorobami przenoszonymi drogą płciową. Dziecko, które nie śpi wystarczającej liczby godzin może w przyszłości mieć poważne problemy zdrowotne i kłopoty z nauką ${ }^{13}$.

Informacje zawarte $\mathrm{w}$ wielu publikacjach są niepokojące. Dzieci i młodzież zbyt często korzystają z urządzeń mobilnych. Nie wiąże się to z rozwojem ich pasji, czy talentów, a jedynie stanowi proste i łatwe zorganizowanie wolnego czasu. Dla wielu osób dorosłych jest to sytuacja ułatwiająca codzienne funkcjonowanie $\mathrm{w}$ pracy $\mathrm{i} \mathrm{w}$ domu, bowiem dzieci zajęte grą, filmem nie wymagają od rodziców szczególnej uwagi. Warto jednak zastanowić się, jakie wiążą się z tą sytuacją konsekwencje i jakie będą tego dalsze skutki. Dorośli muszą pamiętać, że relacje z dzieckiem są fundamentem do partnerstwa i bliskości między nimi w dorosłym życiu.

\section{Badania własne - studium indywidualnego przypadku}

Od 11 do 27 lipca 2018 roku przeprowadziłam badania w jednej z podtarnowskich wsi. Podmiotem badań był siedmioletni Wojciech wraz z najbliższymi osobami - mamą, bratem, babcią. Przedmiotem badań była zależność chłopca od urządzeń elektronicznych. Podczas prowadzonych badań wykorzystałam metodę studium indywidualnego przypadku, umożliwiającą mi przybliżenie sylwetki ucznia klasy pierwszej szkoły podstawowej, który ma bardzo duże problemy z racjonalnym korzystaniem z Internetu.

Według Tadeusza Pilcha i Teresy Bauman:

metoda indywidualnych przypadków jest sposobem badań polegającym na analizie jednostkowych losów ludzkich uwikłanych w określone sytuacje wychowawcze lub na analizie konkretnych zjawisk natury wychowawczej poprzez pryzmat jednostkowych biografii ludzkich z nastawieniem na opracowanie diagnozy przypadku lub zjawiska w celu podjęcia działań terapeutycznych ${ }^{14}$.

${ }^{13}$ M. Desmurget, Teleogtupianie. O zgubnych skutkach ogladania telewizji (nie tylko przez dzieci), Warszawa 2012, s. 249.

${ }^{14}$ T. Pilch, T. Bauman, Zasady badań pedagogicznych. Strategie jakościowe i ilościowe, Warszawa 2001, s. 78. 
$\mathrm{W}$ badaniach zastosowałam technikę wywiadu z siedmioletnim chłopcem, jego mamą, rodzeństwem i babcią. Biorąc pod uwagę technikę badawczą, stworzyłam arkusz wywiadu z poszczególnymi członkami rodziny.

Wojciech urodził się w grudniu 2010 roku. Uczęszcza do I klasy szkoły podstawowej. Ze względu na liczne problemy edukacyjne, będzie powtarzał klasę. Chłopiec wychowuje się w niepełnej rodzinie. Matka ma 40 lat, wykształcenie wyższe. Pracuje w dużej firmie budowanej. Jest kobietą spokojną, łagodną. Ojciec zmarł $w$ wieku 38 lat. Od jego śmierci minęły 4 lata i pomoc w wychowaniu dwóch synów zaoferowała teściowa. W rodzinie oprócz Wojciecha wychowuje się jego starszy brat Paweł. Ich warunki bytowe można określić jako bardzo dobre. Kobiety - mama i babcia wraz z dziećmi mieszkają w domu jednorodzinnym. Do dyspozycji mają 5 pokoi, łazienkę, przedpokój i kuchnię. Gospodarstwo domowe wyposażone jest w nowoczesny sprzęt, to jest lodówkę, pralkę automatyczną, telewizor kolorowy, wideo, playstation $\mathrm{i}$ inne. Wojciech ma w domu bardzo dobre warunki do nauki i wypoczynku. $\mathrm{W}$ wieku 4 lat na prezent urodzinowy otrzymał tablet $\mathrm{z}$ dostępem do Internetu. Początkowo korzystał z niego pod nadzorem mamy lub babci. Później już posługiwał się nim bardzo sprawnie samodzielnie i był to dla niego główny sposób spędzenia wolnego czasu. Po 10 miesiącach mama chłopca dostrzegła problem - nadmierne korzystanie z urządzenia i jak mówi:

„kiedy poprosiłam go o wyprowadzenie psa na dwór, zupetnie nie reagował. Miatam wrażenie, że mnie nie styszy. Podeszłam do niego blizej, ale on nawet na mnie nie spojrzat. Caty czas patrzyt w ekran. Chyba grat, nie pamiętam dokładnie".

Chłopiec korzystał z tabletu w obecności mamy około 2 godzin dziennie. Kobieta przyznaje jednak, że miała świadomość, iż po powrocie z przedszkola, kiedy był pod opieką babci korzystał z tego urządzenia:

"wiedziałam, że Wojtek bardzo czekat na to, kiedy przyjdzie po niego babcia i zabierze go do domu. Powrót oznaczał gre na tablecie. Moja teściowa była z tego zadowolona, bo miata chwile spokoju. Ja mam świadomość tego, że Wojtek byt trudnym dzieckiem, ale teraz czasami nie mam pojęcia co mogę zmienić".

Do szkoły poszedł niechętnie. Często płakał, domagał się pozostania w domu. Miał trudności z nawiązaniem nowych kontaktów z rówieśnikami. Pojawiły się też pierwsze trudności w nauce. Okazało się, że chłopiec ma duże problemy ze skupieniem uwagi; dłuższa koncentracja szybko go męczy, bardzo łatwo się rozprasza. Mama chłopca wspomina pierwsze konsultacje z nauczycielką chłopca:

"batam się tego spotkania, bałam się, co powie mi Pani Jolanta. Była miła $i$ serdeczna. Na samym poczatku powiedziała, że Wojtek potrafi pracować efektywnie 
nad czymś co go interesuje, ale wymaga nadzoru i ciagłego zwracania uwagi na wykonywane przez niego zadanie. Ucieszyłam się, że nie jest tak źle, że Wojtek radzi sobie w szkole, choć wiedziałam, że wizyta w poradni i uzyskana opinia lub orzeczenie na pewno będzie konieczne. Rozmawiałam o tym z wychowawczynia, ale po chwili zupetnie się to dla mnie nie liczyło, bo dowiedziałam się, że mój syn mnie okłamuje. Okazało się, że Wojtek przynosi do szkoty telefon komórkowy, który otrzymał w prezencie od swojego wujka. Doskonale wiedziat, że jest to zabronione w szkole, jednak złamat zasady i go przynosit".

Podczas indywidualnej rozmowy z nauczycielką kobieta dostrzegła, że problem nadmiernego korzystania z tabletu i telefonu komórkowego przeniósł się również do szkoły. Po 3 miesiącach nauki w szkole chłopiec został skierowany przez wychowawcę do Poradni Psychologiczno-Pedagogicznej w Tarnowie. W styczniu otrzymał orzeczenie o potrzebie kształcenia specjalnego. Przeprowadzone badania psychologiczne wykazały przeciętny rozwój intelektualny. Koordynacja wzrokowo-ruchowa z niewielkim deficytem. Graficznie pismo mniej sprawne. Wojciech prawidłowo rozpoznaje drukowane małe i wielkie litery alfabetu, natomiast miał trudności z zapisaniem rzadziej używanych liter. Chłopiec czyta wolno i popełnia dużo błędów, nawet podczas czytania wyrazów krótkich, dwusylabowych. Czytanie staje się dla niego czynnością męczącą, co utrudnia zapamiętywanie czytanych treści. W zakresie pojęć matematycznych zauważa się braki w podstawowych wiadomościach i umiejętnościach. Przez cały rok szkolny chłopiec nie był w stanie nadrobić wszystkich zaległości. Jego wychowawczyni i mama zdecydowały, że najlepszym rozwiązaniem będzie powtórzenie klasy.

"Nie było to dla mnie łatwe, obawiałam się, co powiedza najbliżsi. Zdecydowałam jednak, że tak będzie najlepiej" - mówi kobieta.

Natomiast, podczas rozmowy z babcią chłopca dowiedziałam się, że jej zdaniem to rozwiązanie nie jest słuszne, bo wszystkie zaległości można nadrobić w czasie wakacji. Kiedy zapytałam 64-latkę, co jej wnuk robi w czasie wolnym, odpowiedziała:

„Wojtek w przyszłości będzie chyba trenerem. Teraz cały czas gra w pitke nożna na tablecie. Styszę, jak gra mu muzyczka. Kiedy odwiedza nas mój syn, często proponuje mu wspólna gre, ale on nie korzysta. Zawsze chętny jest za to Pawet. To sa zupetne przeciwieństwa. Paweł jest ruchliwy, pełen energii, Wojtek spokojniejszy".

W celu uzyskania szczegółowych informacji na temat wnuka, zapytałam babcię Irenę, czy Wojtek w każdej sytuacji jest taki spokojny i opanowany. Wtedy dopiero kobieta odpowiedziała, że Wojciech jest spokojny, kiedy ma 
w zasięgu ręki telefon lub gdy obieca się mu, że po wykonanej czynności będzie mógł grać na tablecie. Podczas rozmowy babcia chłopca opisała sytuację, kiedy dziecko stawało się wręcz agresywne, jeżeli ktoś chciał mu zabrać urządzenie.

"Pamiętam taka sytuację, kiedy przyjechali nas odwiedzić znajomi. Byłam wtedy sama z chłopcami, bo Iwona (mama Wojtka i Pawła) była w pracy. Chciałam pochwalić się wnukami. Zawołałam ich z góry. Paweł po chwili zszedt, przywitał się $z$ gośćmi, usiadt, rozmawiat. Wojtka nie było dość długo, więc po niego poszłam. Wtedy nie grat, patrzył na coś $i$ chyba czytat z ekranu. Był zły, bo nie działał mu jakiś program lub gra. Poprositam, by to zostawit i poszedł na dót, a on zaczą krzyczeć, że nigdzie nie pójdzie, że ma zepsuty telefon. Krzyczat i kopat. Zadzwoniłam wtedy po Iwone" - wspomina babcia chłopca.

Opisaną sytuację wykorzystałam podczas rozmowy z mamą Wojtka. Pani Iwona potwierdziła, że miała ona miejsce i kilkukrotnie się powtórzyła. Niekiedy zdarzało się, że chłopiec pluł i przeklinał matkę oraz babcię, kiedy nie chciały oddać mu urządzeń. Podczas rozmów zapytałam wówczas obie Panie, co zamierzają zrobić w związku z tymi sytuacjami. Pani Iwona odpowiedziała:

„postanowiłam, że nie będę ulegać Wojtkowi. Jego krzyk i złość nie działają na mnie tak jak wcześniej. Kiedy mama (babcia chłopca) wyjedzie do sanatorium, zabieram mu tablet. Nie wiem jak on to zniesie, ale wiem, że musze tak zrobić. Będe wtedy cały czas w domu. Zorganizowałam już sobie czas. Myśle, że takie szybkie zerwanie z urządzeniami nie jest możliwe, dlatego zapisatam Wojtka na naukę programowania dla dzieci. Będzie wtedy wśród rówieśników. Tablet będzie do jego dyspozycji na moich warunkach".

Babcia chłopca przyznała, że te sytuacje mogą wynikać z nadmiernego korzystania z tabletu i telefonu komórkowego. Zgadza się z decyzją Pani Iwony, aby ograniczyć Wojtkowi czas zajmowania się tymi urządzeniami. Jest jednak świadoma trudności związanych z wykonaniem tego zadania.

\section{Podsumowanie}

Urządzenia mobilne dla niektórych dzieci stanowią nieodłączny element funkcjonowania. Nadmierne korzystanie z urządzeń elektronicznych przez najmłodszych staje się obecnie zjawiskiem bardzo popularnym. Coraz częściej na osiedlowych podwórkach, placach zabaw, ulicach można dostrzec dzieci i młodzież zapatrzonych w ekrany telefonów lub nowoczesnych tabletów. Ten młody człowiek zafascynowany ulubioną grą jest rozkojarzony, nie 
zwraca uwagi na rówieśników, inne osoby, czy nadjeżdżające samochody. Jest to zjawisko niezwykle niebezpieczne, biorąc pod uwagę choćby natężenie ruchu na drogach. Niewątpliwie, jest to bardzo niepokojące zjawisko - tak silne zafascynowanie dzieci urządzeniami mobilnymi podczas codziennych sytuacji.

\section{BIBLIOGRAFIA}

Bauer J., Co z tą szkota? Siedem perspektyw dla uczniów, nauczycieli i rodziców, Wydawnictwo Dobra Literatura, Słupsk 2015.

Desmurget M., Teleogtupianie. O zgubnych skutkach ogladania telewizji (nie tylko przez dzieci), Wydawnictwo Czarna Owca, Warszawa 2012.

Hüther G., Hauser U., Wszystkie dzieci sa zdolne. Jak marnujemy wrodzone talenty, Wydawnictwo Dobra Literatura, Słupsk 2014.

Jull J., Kryzys szkoty. Co możemy zrobić dla uczniów, nauczycieli i rodziców? Wydawnictwo MiND, Podkowa Leśna 2014.

Klim-Klimaszewska A., Pedagogika przedszkolna, ERICA, Warszawa 2010.

Kupisiewicz C., Kupisiewicz M., Stownik pedagogiczny, Wydawnictwo Naukowe PWN, Warszawa 2009.

Okoń W., Stownik pedagogiczny, Państwowe Wydawnictwo Naukowe, Warszawa 1984.

Pilch T., Bauman T., Zasady badań pedagogicznych. Strategie jakościowe i ilościowe, Wydawnictwo Akademickie ŻAK, Warszawa 2001.

Spitzer M., Cyberchoroby. Jak cyfrowe życie rujnuje nasze zdrowie, Wydawnictwo Dobra Literatura, Słupsk 2016.

Waloszek D., Pedagogika przedszkolna. Metamorfoza statusu i przedmiotu badań, Wydawnictwo Naukowe Akademii Pedagogicznej, Kraków 2006.

\section{Netografia}

http:/ / mamatatatablet.pl/ [dostęp: 25.02.2019]. 